\title{
Vitamin D Levels and Vitamin D Receptor (VDR) Gene Polymorphisms in Inactive Hepatitis B Virus Carriers
}

\author{
Suleyman Albas ${ }^{1}$, Esra Meltem Koc ${ }^{1}$, Salih Atakan Nemli ${ }^{2}$, Tuna Demirdal ${ }^{2}$, Mustafa Soyoz ${ }^{3}$, Saliha Aksun ${ }^{4}$, Melih \\ Kaan Sozmen ${ }^{5}$, Candeger Avsar ${ }^{4}$ and Burcu Cerci Gurbuz ${ }^{3}$ \\ ${ }^{1}$ Department of Family Medicine, Faculty of Medicine, Katip Celebi University, Ataturk Training and Research Hospital, Izmir, Turkey \\ ${ }^{2}$ Department of Infectious Diseases and Clinical Microbiology, Faculty of Medicine, Katip Celebi University, Ataturk Training and \\ Research Hospital, Izmir, Turkey \\ ${ }^{3}$ Department of Medical Biology, Faculty of Medicine, Katip Celebi University, Ataturk Training and Research Hospital, Izmir, Turkey \\ ${ }^{4}$ Department of Medical Biochemistry, Faculty of Medicine, Katip Celebi University, Ataturk Training and Research Hospital, Izmir, \\ Turkey \\ ${ }^{5}$ Department of Public Health, Faculty of Medicine, Katip Celebi University, Ataturk Training and Research Hospital, Izmir, Turkey
}

\begin{abstract}
Objective: To evaluate the vitamin D receptor (VDR) gene polymorphisms and vitamin D levels in inactive hepatitis $B$ virus (HBV) carriers.

Study Design: A cross-sectional analytical study.

Place and Duration of Study: From March to September 2017 at the Izmir Katip Celebi University (iKCU) Ataturk Training and Research Hospital, Izmir, Turkey.

Methodology: Eighty-six inactive hepatitis B carriers and 86 control individuals were included in the study. Individuals with diseases or under medication that could affect vitamin $D$ levels were excluded from the study. Serum vitamin $D$ concentration of $>30 \mathrm{ng} / \mathrm{mL}$ was considered as sufficient, between $20-30 \mathrm{ng} / \mathrm{mL}$ as insufficient, $<20 \mathrm{ng} / \mathrm{mL}$ as deficiency and $<10 \mathrm{ng} / \mathrm{mL}$ as severe deficiency. VDR gene Bsm I, Fok I, Apa I and Taq I polymorphisms were identified by the polymerase chain reaction-fragment length polymorphism (PCR-RFLP) method.

Results: When vitamin D levels were examined, $52.3 \%(n=45)$ of the inactive HBV carriers had severe deficiency, $38.4 \%(n=$ 33) deficiency, $7 \%(n=6)$ insufficiency; $45.3 \%(n=39)$ of the control group had severe deficiency, $43 \%(n=37)$ deficiency, and $7 \%(n=6)$ insufficiency. There was no statistically significant relationship between VDR gene and Bsm I, Fok I, Apa I, Taq I polymorphisms and vitamin $D$ levels in inactive hepatitis B carriers and control group $(p>0.05)$.

Conclusion: Vitamin $D$ deficiency is highly prevalent both among control population as well as in chronic hepatitis patients.
\end{abstract}

Key Words: Inactive HBV carrier, Vitamin D, Polymorphism, Vitamin D receptor (VDR).

How to cite this article: Albas S, Koc EM, Nemli SA, Demirdal T, Soyoz M, Aksun S, Sozmen MK, Avsar C, Gurbuz BC. Vitamin D Levels and Vitamin D Receptor (VDR) Gene Polymorphisms in Inactive Hepatitis B Virus Carriers. J Coll Physicians Surg Pak 2021; 31(04):393-398.

\section{INTRODUCTION}

Although there is a significant reduction in the incidence of acute HBV infection with effective vaccination programmes nowadays, hepatitis $B$ virus continue to be an important cause of mortality and morbidity, releated with acute and chronic liver diseases. ${ }^{1,2}$ According to World Health Organization (WHO), approximately 240 million people are affected by chronic HBV infections. ${ }^{3,4}$

Correspondence to: Dr. Suleyman Albas, Department of Family Medicine, Faculty of Medicine, Katip Celebi University, Ataturk Training and Research Hospital, Izmir, Turkey

E-mail: albasleyman@yahoo.com.tr

Received: November 04, 2019; Revised: February 25, 2021; Accepted: March 15, 2021

DOI: https://doi.org/10.29271/jcpsp.2021.04.393
Hepatitis B virus is an enveloped, double-stranded DNA virus in the genus orthohepadnovirus of the Hepadnaviridaefamily. Countries that hepatitis B surface antigen ( $\mathrm{HbsAg}$ ) seroprevalance between $4-8 \%$ are defined as middle-endemic countries. Studies showed that HBsAg seroprevalance found approximately $4 \%$ in Turkey and accepted as middle-endemic region. ${ }^{1}$

It is known that $15-40 \%$ of hepatitis B virus (HBV) infected patients develop cirrhosis, hepatic failure or hepatocellular carcinoma (HCC); and more than 600.000 people die due to acute and chronic HBV-related diseases. ${ }^{3,4}$ Acute disease may manifest itself in different clinical forms as subclinical or anicteric hepatitis to fulminant hepatitis. More than six months positivity of hepatitis $B$ surface antigen (HBsAg) is indicative for chronicity. Chronic HBV infection can be classified in five different stages; immune tolerant phase, immune reactive phase, inactive hepatitis $B$ carrier state, HBeAg negative chronic hepatitis and HBsAg negative phase. ${ }^{5}$ 
Table I: Comparison of biochemical characteristics of groups.

\begin{tabular}{|c|c|c|c|}
\hline Parameters & $\begin{array}{c}\text { Inactive HBV carriers ( } n=86 \text { ) Median } \\
\text { (IQR) }\end{array}$ & Controls ( $n=86$ ) Median (IQR) & p-value \\
\hline 25(OH)D3 (ng/mL) & $9.85(6.88-13.7)$ & $10.95(6.98-15.6)$ & $0.347^{*}$ \\
\hline TSH (mlU/L) & $1.45(1.0-2.1)$ & $1.48(1.0-2.1)$ & $0.734^{*}$ \\
\hline PTH $(p g / m L)$ & $25.4(13.2-37.7)$ & $12.0(7.2-24.4)$ & $<0.001^{*}$ \\
\hline $\mathrm{Ca}(\mathrm{mg} / \mathrm{dl})$ & $9.3(9.0-9.6)$ & $9.20(8.9-9.4)$ & $0.074^{*}$ \\
\hline $\mathrm{Mg}(\mathrm{mg} / \mathrm{dl})$ & $2.4(2.3-2.7)$ & $2.2(2.1-2.4)$ & $<0.001 *$ \\
\hline Albumin (gr/dl) & $4.50(4.3-4.6)$ & $4.40(4.2-4.5)$ & $0.011^{*}$ \\
\hline Creatine $(\mathrm{mg} / \mathrm{dl})$ & $0.76(0.68-0.8)$ & $0.75(0.68-0.86)$ & $0.656 *$ \\
\hline BUN (mg/dl) & $12.0(10-15.25)$ & $12.0(10-14)$ & $0.690 *$ \\
\hline AST (U/L) & $19.0(15-21.3)$ & $16.0(13-19)$ & $<0.001 *$ \\
\hline $\mathrm{ALT}(\mathrm{U} / \mathrm{L})$ & $20.5(15-26)$ & $10.0(7-14)$ & $<0.001 *$ \\
\hline $\operatorname{ALP}(\mathrm{U} / \mathrm{L})$ & $71.5(57.5-88.3)$ & $63.5(52-78)$ & $0.012 *$ \\
\hline Parameters & $\begin{array}{l}\text { İnactive HBV Carriers }(n=86) \\
\text { Mean } \pm \text { SD }\end{array}$ & Controls $(n=86)$ Mean \pm SD & $\begin{array}{l}\text { Statistical analysis } \\
\text { p value }\end{array}$ \\
\hline Total protein (gr/dl) & $7.33 \pm 0.49$ & $7.57 \pm 0.49$ & $0.002 * *$ \\
\hline Uric Acid (mg/dl) & $4.8 \pm 1.0$ & $4.5 \pm 1.3$ & $0.172 * *$ \\
\hline Phosphate (mg/dl) & $3.3 \pm 0.58$ & $3.6 \pm 0.59$ & $0.001 * *$ \\
\hline
\end{tabular}

Table II: Correlation of biochemical values and socio-demographic characteristics with vitamin D level and linear regression model.

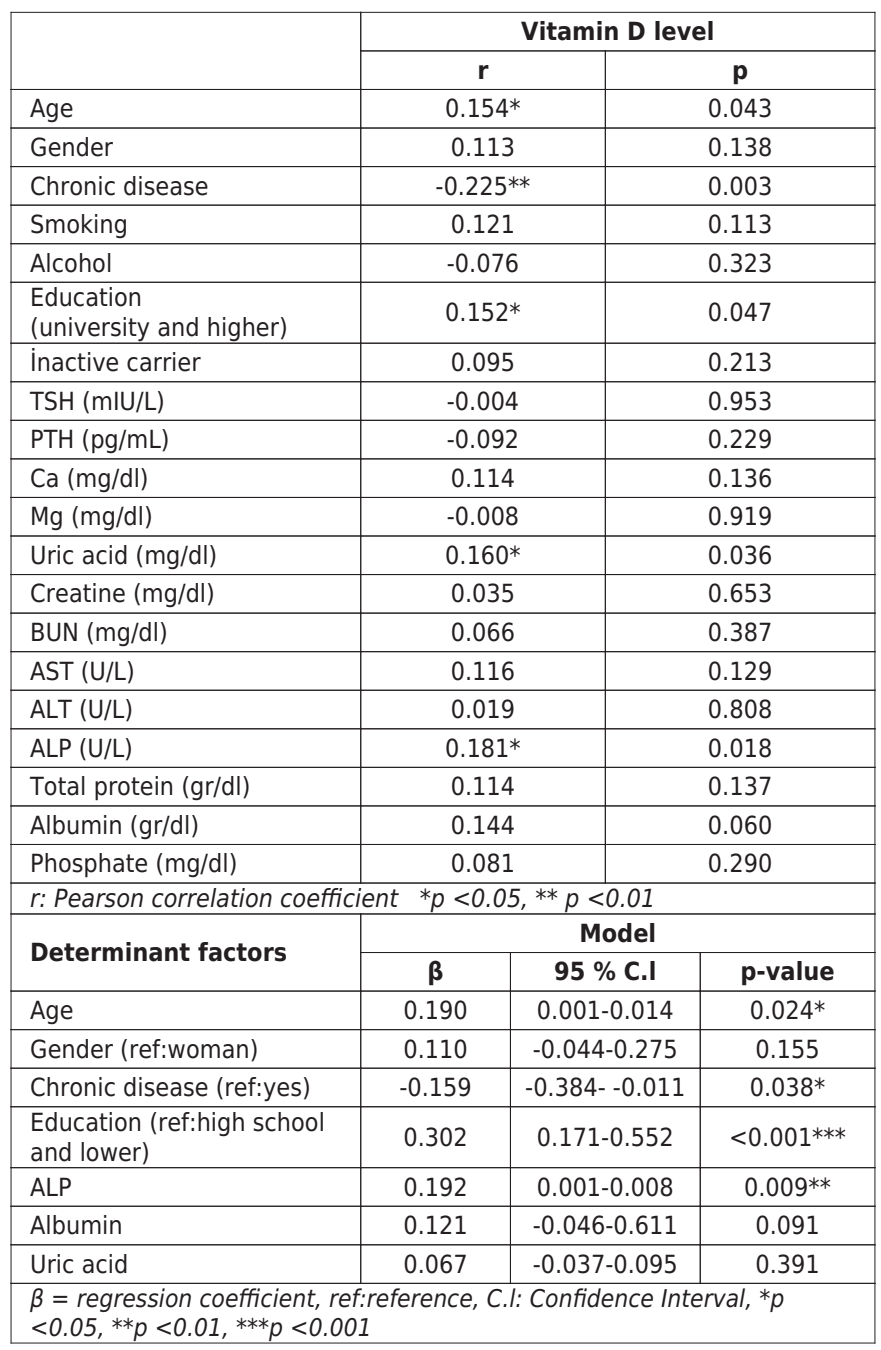

The inactive hepatitis $B$ carrier state were defined as normal serum aspartate and alanine aminotransferase (AST, ALT), serum HBV deoxyribonucleic acid (HBV-DNA) levels below 2000 $\mathrm{IU} / \mathrm{mL}, \mathrm{HBsAg}$ positivity longer than six months, a negative antiHDV antibody, hepatitis B early antigen (HBeAg) negativity and antibody to $\mathrm{HBeAg}$ (Anti-HBe) positivity, and absence of a significant histopathologic change in liver biopsy. ${ }^{1}$

Vitamin D is an important immunomodulator and secosteroid hormone for general health and well-being that is soluble in fat and plays a role in bone and calcium metabolism. It has been shown that Vitamin D deficiency play an important role in the development of many autoimmune diseases, type 1 diabetes mellitus, inflammatory bowel diseases, multiple sclerosis, heart diseases and malignancies. Systemic antimicrobial effects of Vitamin D has reported in some acute and chronic diseases. ${ }^{6}$

Vitamin D deficiency leads to adverse clinical outcomes in HBV-infected patients and it has been reported that supplementation of vitamin D may be helpful in the treatment of HBV-associated chronic liver diseases. ${ }^{7}$ In a study comparing serum vitamin D levels of chronic hepatitis B patients and healthy subjects, levels of vitamin $D$ were lower in chronic hepatitis B patients. ${ }^{8}$ It is recommended that routine vitamin D levels be tested in patients with chronic hepatitis. ${ }^{9}$ Motor et al. reported that vitamin $D$ may stimulate the antiviral immune response and have a protective effect on necroinflammation and liver fibrosis in inactive HBV carriers. ${ }^{10}$

Vitamin D shows its effects via vitamin D receptor (VDR), an intracellular protein. VDR gene locus located in 12q13.1 region, contains 11 exons and spans 100 kilobases (kb). Consist of genetic differences in VDR gene can cause significant defects by altering gene activation, calcium metabolism, cell proliferation and protein sequence in the immune system. 
Table III: Relationship between Vitamin D levels and VDR gene polymorphisms of participants.

\begin{tabular}{|c|c|c|c|c|c|c|c|c|}
\hline \multirow{2}{*}{\multicolumn{3}{|c|}{$\begin{array}{l}\text { Parameter } \\
\text { Vitamin D (ng/ml) }\end{array}$}} & \multicolumn{3}{|c|}{ Inactive HBV carriers $(n=86)$} & \multicolumn{3}{|c|}{ Controls $(n=86)$} \\
\hline & & & $<20$ & $\geq 20$ & $\mathbf{P}$ & $<20$ & $\geq 20$ & $\mathbf{P}$ \\
\hline \multirow{3}{*}{ Apa I } & AA & \multirow{3}{*}{$\begin{array}{l}n \\
\%\end{array}$} & $\begin{array}{l}26 \\
30.2\end{array}$ & 2.3 & \multirow{3}{*}{0.866} & $\begin{array}{l}25 \\
29.1\end{array}$ & $\begin{array}{l}4 \\
4.7\end{array}$ & \multirow{3}{*}{0.893} \\
\hline & $\mathrm{Aa}$ & & $\begin{array}{l}37.2 \\
43\end{array}$ & $\begin{array}{l}4.5 \\
4.7\end{array}$ & & $\begin{array}{l}41.1 \\
47.7\end{array}$ & $\begin{array}{l}5 \\
5.8\end{array}$ & \\
\hline & aa & & $\begin{array}{l}15 \\
17.4\end{array}$ & $\begin{array}{l}2 \\
2.3\end{array}$ & & $\begin{array}{l}10 \\
11.6\end{array}$ & $\begin{array}{l}1 \\
1.2\end{array}$ & \\
\hline \multirow{3}{*}{ Taq I } & $\pi$ & \multirow{3}{*}{$\begin{array}{l}n \\
\%\end{array}$} & $\begin{array}{l}33 \\
38.4\end{array}$ & $\begin{array}{l}3 \\
3.5\end{array}$ & \multirow{3}{*}{0.914} & $\begin{array}{l}35 \\
40.7\end{array}$ & $\begin{array}{l}5 \\
5.8\end{array}$ & \multirow{3}{*}{0.096} \\
\hline & $\mathrm{Tt}$ & & $\begin{array}{l}33 \\
38.4\end{array}$ & $\begin{array}{l}4 \\
4.7\end{array}$ & & $\begin{array}{l}38 \\
44.2\end{array}$ & $\begin{array}{l}3 \\
3.5\end{array}$ & \\
\hline & tt & & $\begin{array}{l}12 \\
14\end{array}$ & $\begin{array}{l}1 \\
1.2\end{array}$ & & $\begin{array}{l}3 \\
3.5\end{array}$ & 2.3 & \\
\hline \multirow{3}{*}{ Fok I } & $\mathrm{FF}$ & \multirow{3}{*}{$\begin{array}{l}n \\
\%\end{array}$} & $\begin{array}{l}44 \\
51.2\end{array}$ & $\begin{array}{l}3 \\
3.5\end{array}$ & \multirow{3}{*}{0.101} & $\begin{array}{l}45 \\
52.3\end{array}$ & $\begin{array}{l}7 \\
8.1\end{array}$ & \multirow{3}{*}{0.308} \\
\hline & $\mathrm{Ff}$ & & $\begin{array}{l}30 \\
34.9\end{array}$ & $\begin{array}{l}3 \\
3.5\end{array}$ & & $\begin{array}{l}29 \\
33.7\end{array}$ & 2.3 & \\
\hline & $\mathrm{ff}$ & & $\begin{array}{l}4.5 \\
4.7\end{array}$ & $\begin{array}{l}2.3 \\
2.3\end{array}$ & & $\begin{array}{l}2 \\
2.3\end{array}$ & $\begin{array}{l}1 \\
1.2\end{array}$ & \\
\hline \multirow{3}{*}{ Bsm I } & BB & \multirow{3}{*}{$\begin{array}{l}n \\
\%\end{array}$} & $\begin{array}{l}13 \\
15.1\end{array}$ & 2.3 & \multirow{3}{*}{0.699} & $\begin{array}{l}14 \\
16.3\end{array}$ & $\begin{array}{l}3 \\
3.5\end{array}$ & \multirow{3}{*}{0.662} \\
\hline & $\mathrm{Bb}$ & & $\begin{array}{l}41 \\
47.7\end{array}$ & $\begin{array}{l}3 \\
3.5\end{array}$ & & $\begin{array}{l}39 \\
45.3\end{array}$ & $\begin{array}{l}44 \\
4.7\end{array}$ & \\
\hline & $b b$ & & $\begin{array}{l}24 \\
27.9\end{array}$ & $\begin{array}{l}3 \\
3.5\end{array}$ & & $\begin{array}{l}23 \\
26.7\end{array}$ & $\begin{array}{l}3 \\
3.5\end{array}$ & \\
\hline
\end{tabular}

Many polymorphisms have been identified in the VDR gene; and the most known of them are Fok I ( $T>C$ rs2228570), Bsm I (G>A rs1544410), Apa I (C>A rs7975232) and Taq I ( $T>C$ rs731236) polymorphisms. It has been shown VDR polymorphisms associated with hepatic fluctuations, HBeAg positivity and prognosis of inactive HBsAg carriers. ${ }^{11}$ Maryam et al. found that VDR gene polymorphisms, which has been associated with malignancies, infectious diseases and autoimmune diseases, is a significant risk factor of rheumatoid arthritis as well as osteoarthritis onset in Pakistani population. ${ }^{12}$

The aim of this study was to investigate the incidence of vitamin $D$ deficiency and/or insuffiency and VDR gene polymorphisms in inactive HBV carriers and control group.

\section{METHODOLOGY}

Cross-sectional study was carried out between March 1, 2017 and September 1, 2017 in İmir Katip Celebi University (IKCU) Atatürk Training and Research Hospital Infectious Diseases and Family Medicine Polyclinics. The ethical approval was obtained from the local Ethics Committee (Oct. 19, 2017, decision number 8).

The case group was formed from patients who admitted to Infectious Diseases Polyclinic as inactive hepatitis B carriers. The control group was formed by individuals who were admitted to the Family Medicine Polyclinic for an health problem or as a patient escort during March-April 2017.

This study included two groups as case and control, aging between 18-85 years. Inclusion criteria of inactive carrier included: normal serum AST and ALT, serum HBV-DNA level under $2000 \mathrm{IU} / \mathrm{ml}$, HBsAg positivity longer than 6 months, negative anti-HDV antibody, HBeAg negativity, Anti-HBe posi- tivity. HBsAg and Anti HBs negative individuals were included in the control group. Exclusion criteria for study included: autoimmune disease, metabolic bone disease, chronic kidney disease, chronic liver disease, thyroid-parathyroid disease, diabetes mellitus, malignancy, alcoholism, immunosuppression, liver transplantation, pregnancy or breastfeeding, psychiatric disease that disrupts the ability to answer questions, using medication that vitamin $D$, calcium, hormone therapy, glucocorticosteroid, antituberculosis, antiepileptic the last six months.

A data form, assessing socio-demographic characteristics, was administered to the patients with face-to-face interview technique after obtaining constent. Blood samples were collected from the inactive HBV carriers. The following parameters were examined: $\mathrm{HBsAg}$, Anti HBs, Anti $\mathrm{HBC}$ IgG, HBeAg, Anti HBe, HBV DNA, AST, ALT, ALP, BUN, creatine, total protein, albumin $25(\mathrm{OH}) \mathrm{D}, \mathrm{PTH}, \mathrm{TSH}, \mathrm{Ca}, \mathrm{Mg}$, phosphate, uric acid and VDR gene polymorphism. The study was supported by the IKCU Scientific Research Projects Unit. HBsAg, Anti-HBs, Anti-HBc IgG, 25-hydroxy vitamin D, TSH and PTH levels were analysed by chemiluminescence microparticle immunoassay (CMIA) method. BUN, creatine, uric acid, Ca, Mg, P, ALP, AST, ALT, total protein, albumin levels were examined by spectrophotometrically and VDR gene polymorphisms were examined by PCR-RFLP method.

Serum vitamin D levels were categorized as follows: concentration of $>30 \mathrm{ng} / \mathrm{mL}$ was considered as sufficiency, between 20-30 $\mathrm{ng} / \mathrm{mL}$ as insufficiency, <20 ng / $\mathrm{mL}$ as deficiency and $<10 \mathrm{ng} / \mathrm{mL}$ as severe deficiency. ${ }^{11}$

The sample size was calculated as 172 with $80 \%$ power, $5 \%$ error margin using NCSS and PASS programmes. It was aimed to reach 180 people with $5 \%$ missing. Four carrier and 4 control were excluded from the study, who were diag- 
nosed with thyroid dysfunction, autoimmune disease and drug use that could affect vitamin D levels. A total of 172 subjects, 86 inactive carriers and 86 control individuals were included in the study. The SPSS 22.0 for Windows was used for statistical analyses. Categorical variables were presented in percentages, continuous variables were presented as mean \pm standard deviation or median (IQR (Q1-Q3)). Normality of the distribution of the data was tested by visual (histogram and probability) and analytical method (Kolmogorov-Smirnov). Chi-square (Student $t$ and Mann-Whitney Utests were used for group comparisons. Pearson correlation was used to show the relationship between two continuous variables. A linear regression model was used in order to evaluate independent effect of variables on Vitamin D levels. Vitamin D levels did not show a normal distribution; hence, we generated a log-linear regression model in order to evaluate independent effect of variables on Vitamin $D$ levels. The independent variables with a $p \leq 0.100$, based on bivariate analyses, were included in the regression model. Exponential of beta $(\beta)$ values were taken and magnitudes were expressed as percent change. A $p$ value $<0.05$ was considered as statistically significant.

\section{RESULTS}

The age of the 172 participants in the study ranged between 19 and 81 , with a mean of $41.5 \pm 13.6$ years. The mean age of the carriers was significantly higher ( $44.58 \pm 12.36$ years) compared to control group (38.43 \pm 14.22 years). Forty-one patients were females $(47.7 \%)$ and 45 patients were males $(52.3 \%)$ among 86 inactive carriers. Fifty-one individuals were females $(59.3 \%)$, and 35 individuals were males $(40.7 \%)$ among 86 control individuals.

When the inactive carriers and control individuals were evaluated by education levels, $15.1 \%(n=13)$ of the carriers, and $36 \%(n=31)$ of the control group had a university or higher degree; and this difference was statistically significant $(p=0.005) .26 .2 \%$ of the participants $(n=45)$ were smoking; $17.4 \%(n=30)$ were using alcohol, $23.3 \%(n=40)$ of the participants had chronic disease. Alcohol usage was lower among inactive hepatitis $B$ carriers compared to control group $(p=0.044)$. Unemployment rates were higher among inactive hepatitis $B$ carriers compared to control group $(p=0.031)$. Smoking, gender and chronic illness did not significantly differ by HBV carriage status $(p=0.862, p=0.126, p>0.999)$. One hundred and sixty-six $(96.5 \%)$ of the study population had vitamin $D$ insufficiency ( $\leq 30 \mathrm{ng} / \mathrm{ml}) .97 .7 \%(\mathrm{n}=84)$ of the carriers; and $95.3 \%(n=82)$ of the control group had vitamin D insufficiency.

The median values for PTH, Mg, albumin, AST, ALT and ALP levels were significantly higher among inactive carriers (all $p<0.05$ ). On the other hand, total protein and phosphate levels were significantly higher among the control group ( $p$ : $0.002, p$ : 0.001). Vitamin D, TSH, Ca, BUN, creatinine, uric acid levels did not differ significantly between groups (Table I).
The correlations between the biochemical values and sociodemographic characteristics with vitamin D level of the participants are shown in the Table II.

In the linear regression analysis, there was a significant correlation between age and vitamin $D$ levels $(\beta=0.190$, exponential beta $=1.21, p=0.024$ ). Likewise, university and more educated people had significantly higher levels of vitamin $D$ than high school and lower education levels $(\beta=0.302$, exp. beta $=1.35, p<0.001)$. The individuals with chronic disease had significantly lower vitamin $D$ levels $(\beta=$ -0.159 , exp. beta $=1.17, p=0.038$ ). There was no significant relationship between gender and vitamin $D$ levels $(\beta=0.110$, exp. beta $=1.12, p=0.155$ ). When laboratory parameters were examined, there was a significant and positive correlation between ALP and vitamin D levels $(\beta=0.192$, exp. beta $=1.21, p=0.009)$. There was no significant relationship between uric acid, albumin with vitamin D levels $(p=0.391$, $\mathrm{p}=0.091$, Table II).

The most common genotypes in the case group for the Apa I, Taq I, Fok I and Bsm I polymorphisms were Aa (47.4), Tt (42.3\%), FF (56.4\%) and $\mathrm{Bb}(52.6 \%)$ respectively. Common genotypes in the control group were Aa (53.9), Tt (50.0\%), FF $(59.2 \%)$ and $\mathrm{Bb}(51.3 \%)$ respectively. There were no statistically significant differences between genotypes frequency of the groups. Also no significant differences were found between the frequency of VDR gene Bsml, Fokl, Apal and Taql polymorphisms and vitamin $D$ levels in inactive HBV carriers and control group (all $p>0.05$, respectively, Table III).

\section{DISCUSSION}

In this study, vitamin $D$ receptor gene polymorphisms and vitamin $D$ levels were evaluated in inactive hepatitis $B$ virus carriers. Vitamin D deficiency is highly prevalent among chronic hepatitis patients both in Turkey and across the world. It is also widely seen in general population.

A study conducted in Turkey that included 35 chronic hepatitis B patients not receiving treatment, 30 naturally immunised individuals, and 30 healthy individuals, the mean vitamin $D$ levels were reported as $7.65 \pm 4.19 \mathrm{ng} / \mathrm{mL}, 12.1 \pm$ $7.13 \mathrm{ng} / \mathrm{mL}$ and $14.17 \pm 9.18 \mathrm{ng} / \mathrm{mL}$ respectively. Vitamin $D$ levels were significantly lower in patients with chronic hepatitis B compared to other groups $(p<0.001) .{ }^{13}$ The relationship between HBV-DNA and HBeAg levels and vitamin D levels was not investigated in this study. Studies in this topic have revealed that vitamin D levels are associated with viral replication and the progression of chronic liver disease, and correction of deficiency has been reported to have a positive effect on the treatment of liver diseases. ${ }^{7}$

Chen et al. emphasised that vitamin $D$ deficiency is dangerous for chronic hepatitis B patients. Vitamin D levels can be elevated with effective antiviral therapy. In another study, it was emphasised that vitamin D deficiency or insuffi- 
ciency is a common condition among patients with chronic liver diseases such as Hepatitis B and Hepatitis C. Hence, it was suggested that the treatment of deficiency might have beneficial effect for reducing the progression of chronic liver diseases. ${ }^{14,15}$ Wong et al. reported that $82 \%(n=348)$ of 426 participants with chronic hepatitis had vitamin $D$ deficiency in a study conducted in Hong Kong. They reported a significant correlation between male gender, young age, low platelet level, high bilirubin level, high creatinine level and low-grade of liver disease with vitamin D elevation. ${ }^{16}$

In another study, Chan et al. reported that 93\% $(n=687)$ of 737 chronic hepatitis patients had vitamin D deficiency. They found significiant association between young age, low uric acid levels, HBeAg positivity, low calcium levels and blood drawing in winter or autumn with low vitamin D levels. ${ }^{17}$ Findings of this study are in line with previous study findings, which reported a significant positive relationship between higher age, higher ALP levels, presence of chronic illness, having an education level equal or higher than university degree with higher vitamin $\mathrm{D}$ levels. This relationship could be due to the fact that the individuals with the following characteristics: being elderly living in Izmir, not working, having higher socio-economical level, being retired and having chronic illness might be more conscious about healthy nutrition and benefiting from sunlight. It was thought that the higher levels of vitamin D among individuals with higher education levels might be due to higher level of general knowledge and health literacy.

A number of studies have been conducted on chronic viral hepatitis associated with VDR gene polymorphisms, and different findings were reported. A meta-analysis suggests that VDR Fokl genotype might has potential role in HBV susceptibility. ${ }^{18}$ Jiawei et al. reported that Fok I polymorphism might be a risk factor for HCC in HBV-infected patients. ${ }^{19}$ In a study conducted by Dayangaç et al. about genotype and allele frequencies of VDR Apo I, Fok I, Taq I polymorphisms in 100 healthy individuals on Turkish population, all three polymorphisms were found to be in equilibrium and polymorphism frequencies did not significantly differ by gender. ${ }^{20}$ In another study conducted among 63 chronic hepatitis patients, 61 inactive carriers, and 59 natural immunised individuals, the researchers found no significant difference in the variant allel frequencies of VDR Taq I, Apa I and TNF- $\alpha 308$ genes among three groups. The role of single nucleotide polymorphisms on the progression of HBV infection was also not reported. ${ }^{21}$

In this study, VDR gene polymorphisms in inactive carriers were similar to control population; there was no significant relationship between being an inactive $\mathrm{HBV}$ carrier and vitamin D levels with Apa I, Fok I, Bsm I, Taq I polymorphisms $(p=0.866, p=0.101, p=0.699, p=0.914$ respectively). When the genotypes and allele frequencies of the 2 groups were examined, the results were similar to Dayangaç et al's study of VDR gene polymorphisms. ${ }^{20}$
The most important limitation may be the collection of study populations during March-April, which might have resulted with higher rates for Vitamin D deficiency. Some variables were not considered which could have impact on Vitamin D levels. Hence, it might be appropriate to consider diet, geographical area lived, and seasonal variation. Vitamin D levels couldn't be evaluated with gold standard methods which require higher cost and workload like HPLC and LC-MS methods.

\section{CONCLUSION}

Vitamin D deficiency is highly prevalent both among control population as well as in chronic hepatitis patients. There was no statistically significant relationship between vitamin D levels with inactive carriage and VDR gene Apa I, Fok I, Taq I, Bsm I polymorphisms.

\section{ACKNOWLEDGMENT:}

The authors thank Izmir Katip Celebi University Scientific Research Projects Unit for providing the necessary funds for this study.

\section{ETHICS COMMITTEE APPROVAL:}

Ethics Committee approval was received from the Izmir Katip Celebi University, Faculty of Medicine, Clinical Research Ethics Committee (Decision No. 8).

\section{CONFLICT OF INTEREST:}

The authors declared no conflict of interest.

\section{AUTHORS' CONTRIBUTION:}

SA: Concept, design, supervision, resource, materials, analysis and/or Interpretatio, data collection and amp; or processing, literature search, writing.

EMK: Concept, design, supervision, resource, analysis and/or Interpretatio, data collection and amp; or processing, literature search, writing, critical reviews.

SAN: Resource, literature search, critical reviews.

TD: Literature search, critical reviews.

MS: Design, supervision, resource, materials, analysis and/or Interpretatio, literature search, writing.

SA: Resource, materials, data collection and amp; or processing.

MKS: Supervision, resource, analysis and/or interpretatio, literature search, critical reviews.

CA: Resource, materials, data collection and amp; or processing.

BCG: Materials, data collection and amp; or processing.

\section{REFERENCES}

1. Tabak F, Yurdaydın C, Kaymakoğlu S, Akarsu M, Akıncı EG, Akkız H, et al. Diagnosis, management and treatment of hepatitis B virüs infection: Turkey 2017 clinical practice guidelines. Turk J Gastroenterol 2017; 28(Suppl 2);73-83. doi: 10.5152/tjg.2017.19.

2. Gürakar M, Malik M, Keskin O, İdilman R. Public awareness 
of hepatitis B infection in Turkey as a model of universal effectiveness in health care policy. Turk J Gastroenterol 2014; 25(3):304-8. doi: 10.5152/tjg.2014.6718.

3. The World Health Organization (WHO) Hepatitis B Fact Sheet. Available from: www.who.int/mediacentre/ factsheets/fs204/en/.

4. Tang L, Covert E, Wilson E. Chronic hepatitis B infection. JAMA 2018; 319(17) 1802-13.

5. European Association for the Study of the Liver (EASL) clinical practice guidelines. Management of chronic hepatitis $B$ virus infection. J Hepatol 2017; 57(1):167-85. doi: 10.1016/ j.jhep.2012.02.010.

6. Pludowski P, Holick MF, Pilz S, Wagner CL, Hollis BW, Grant $W B$, et al. Vitamin D effects on musculo-skeletal health, immunity, autoimmunity, cardio vascular disease, cancer, fertility, pregnancy, dementia and mortality-a review of recent evidence. Autoimmun Rev 2013; 12(10):976-89. doi: 10.1016/j.autrev.2013.02.004.

7. Hoan NX, Khuyen N, Binh MT, Giang DP, Tong HV, Hoan PQ, et al. Association of vitamin $D$ deficiency with hepatitis $B$ virus - related liver diseases. BMC Infec Dis 2016; 16(1):507. doi: 10.1186/s12879-016-1836-0.

8. Hu YC, Wang WW, Jiang WY, Li CQ, Guo JC, Xun YH. Low vitamin $D$ levels are associated with high viral loads in patients with chronic hepatitis B: A systematic review and meta-analysis. BMC Gastroenterol 2019; 19(1):84. doi: 10.1186/s12876-019-1004-2.

9. Moosavy SH, Nejatizadeh A, Davoodian P. Evaluation of vitamin D Levels in patients with hepatitis B virus. Int J Pharmaceutical and Phytopharmacological Res 2019; 9(3): 98-106.

10. Motor S, Koksaldı-Motor V, Dokuyucu R. Investıgatıon of vitamın D levels in patıents with inactıve hepatıtıs B vırus carrier. Acta Medica Mediterranea 2014; 30:793-96.

11. Huang YW, Liao YT, Chen W, Chen CL, Hu JT, Liu CJ, et al. Vitamin $D$ receptor gene polymorphisms and distinct clinical phenotypes of hepatitis B carriers in Taiwan. GenesImmun 2010; 11(1): 87-93. doi: 10.1038/gene. 2009.65.

12. Mukhtar M, Sheikh N, Sukaina SK, Batool A, Fatima N, Mehmood $\mathrm{R}$, et al. Vitamin $\mathrm{D}$ receptor gene polymorphism:
An important predictor of arthritis development. Bio Med Res Int 2019; 8326246:1-8. doi: 10.1155/2019/8326246.

13. Demir C, Demir M. Vitamin D levels in patients with chronic hepatitis $B$ virus infection and naturally immunized individuals. Int MedIns J 2013; 1(1):2. doi: 10.7243/ 2052-6954-1-2.

14. Chen EQ, Bai L, Zhou TY, Fe M, Zhang DM, Tang H. Sustained suppression of viral replication in improving vitamin $D$ serum concentrations in patients with chronic hepatitis B. Scientific RepoRts 2015; 5:15441; 1-8. doi: 10.1038/srep15441.

15. Chen EQ, Shi Y, Tang H. New insight of vitamin D in chronic liver diseases. Hepatobiliary Pancreat Dis Int 2014; 13(6):580-85. doi: 10.1016/ s1499-3872(14)60295-2.

16. LaiHung Wong G, Lik-Yuen Chan $\mathrm{H}$, Chan HY, Tse $\mathrm{CH}$, MeiLing Chim A, Oi-Shan Lo A, et al. Adverse effects of vitamin $D$ deficiency on outcomes of patients with chronic hepatitis B. Clinical GastroenterolHepatol 2015; 13(4):783-90.e1. doi: 10.1016/j.cgh.2014.09.050.

17. Lik-Yuen Chan H, Elkhashab M, Trinh H, Young Tak W, Ma $X$, Chuang $W L$, et al. Association of baseline vitamin D levels with clinical parameters and treatment outcomes in chronic hepatitis B. J Hepatol 2015; 63(5):1086-92. doi: 10.1016/j.jhep.2015.06.025.

18. He Q, Huang Y, Zhang L, Yan Y, Liu J, Song X, et al. Association between vitamin $D$ receptor polymorphisms and hepatitis B virus infection susceptibility: A meta-analysis study. Gene 2018; 645: 105-12. doi: 10.1016/j.gene.2017. 12.027 .

19. Rao J, Wu X, Zhou X, Deng R, Ma Y. Vitamin D receptor fok i polymorphism and risk of hepatocellular carcinoma in HBV-Infected Patients. Hepat Mon 2019; 19(1):e85075. doi: 10.5812/hepatmon.85075.

20. Dayangaç D, Özaydın E, Özbaş Gerçeker F, Coşkun T, ErdemYurter $\mathrm{H}$. The vitamin $\mathrm{D}$ receptor (VDR) gene polymorphism analysis of healthy turkish population. Turkish JBiochemistry 2002; 27:1: 11-16.

21. Tuncbilek S, Aydin K, Hizel K. Vitamin D and tumor necrosis factor-alpha receptor gene polymorphisms in various hepatitis B clinical conditions in Turkey. Gastroenterology Research 2013; 6(5):185-90. doi: 10.4021/ gr544e. 